\author{
Laura Kirvelyte $\dot{e}^{*}$ \\ General Jonas Zemaitis Military Academy of Lithuania
}

\title{
Moldova's Security Strategy: the Problem of Permanent Neutrality
}

Just after declaring its independence in 1991, Moldova encountered several challenges to its national security, the most serious of which were the conflict with the breakaway Transnistria ${ }^{1}$ region and the deployment of Russia's armed forces in the territory of Moldova. Under these circumstances Moldova chose permanent neutrality as a security strategy, ignoring the fact that country didn't meet even minimal requirements for a neutral country. The strategy of neutrality, adopted precipitately, has not added to the minimization of threats to Moldova's national security. Moreover, neutrality has been an obstacle for the state to choose a more suitable and well-balanced security strategy. In addition, declared permanent neutrality could even appear as an obstacle for Moldova in the way towards its strategic goal - EU membership. In this article the peculiarities of Moldova's neutrality and the key problems of state's security strategy are discussed. The factors of Moldova's neutrality, looking from the perspectives of several different approaches of international relations, and Moldova's security dilemmas after the Russian-Georgian war, are analyzed.

\section{Introduction}

Moldova - a small state in Eastern Europe ${ }^{2}$ sandwiched between Ukraine and Romania - has attracted the attention of the international community in early April 2009, when, after falsified parliamentary elections, the massive protests against the falsified victory of the ruling Moldova's Communist Party broke out. Dissatisfied citizens were demanding the organization of a new election. Nevertheless mass protests in Moldova hadn't gained any "colour", these events and processes can be taken as a starting point for a new stage in Moldova's politics ${ }^{3}$. The problems of Moldova's democratization were brought

\footnotetext{
${ }^{*}$ Laura Kirvelyte is a lecturer of the Command and Junior Staff Officer Courses of the Military Academy of Lithuania. Address: Šilo str. 5A, 10322 Vilnius, tel. (+370 5) 2103569, e-mail: laura.kirvelyte@gmail.com. ${ }^{1}$ Also known as "Trans-Dniester" or "Transdniestria".

${ }^{2}$ Moldova's attribution to one or another region - the object of discussions. In the different sources, Moldova has been attributed to different regions: Eastern Europe, South-Eastern Europe, Black Sea Region or even the Balkans.

${ }^{3}$ April 2009 events in Moldova are not referred as "revolution" because of several reasons. First of all, the shift of ruling elites took place purely in institutional way: early elections were organized not because of demand of citizens, but due to Constitutional mechanism (opposition parties two times successively refused to support communists' candidate to the post of the President of the Republic of Moldova). Second, the government, composed of pro-democratic political forces, still holds temporary character-communists used the same Constitutional mechanism of President's election, in the consequence of what in Autumn 2010 the country would hold the second early parliamentary elections.
} 
into the first plan by the April 2009 protest and the processes that followed, though the long-time ignored paradoxes of the state's foreign and security policies were also remembered.

The relevance of the topic of Moldova's security is evident ipso facto Moldova is a small state, located in the area of intersection of the interest zones of the two great powers (in the academic literature this situation is called "the paradox of small state"). Nevertheless, until now the issue of Moldova's security has been "forgotten" in domestic and foreign agendas, ignoring the fact that both the security situation of Moldova and its solution could be considered as a kind of exception in the post-Soviet sphere.

First and foremost, Moldova has been seeking the resolution of a frozen conflict with breakaway Transnistria for almost two decades already. The Transnistrian conflict has not only been the main threat to Moldova's national security, but also the main challenge to the country's sustainable development.

Second, the full decade has passed since the 1999 Organization's for Security and Cooperation in Europe (OSCE) Istanbul summit, during which Russia took the obligation to withdraw its military forces from Georgia and Moldova in several years' period. Russia has failed to fulfil its commitments regarding Moldova, and now Moscow doesn't even consider the renewal of the withdrawal of it's military forces from the territory of Moldova. In this context, Moldova's security situation has been especially complicated by the undetermined presence of the foreign country's military forces in its territory.

Moreover, the Russian-Georgian war, which broke out in August 2008, sounded as if it was a warning for Moldova, informing the latter that it could become the next victim of Russia's aggression. It is worth mentioning that Moldova, as Georgia, seeks to escape from the zone of Russia's domination, and the seeking EU membership is country's strategic goal (in Georgia's case it was NATO membership).

At the beginning of the 90's young Moldova hoped that the principle of permanent neutrality, fixed in the Constitution and main strategic documents, will calm down both Russia and Transnistria and will help to minimize the threats to the state's national security. Thus the hopes attached to the neutrality haven't been realized - today Moldova encounters the same threats to its national security as two decades ago. Moreover, the neutrality strategy threatens to become a serious obstacle for the state to realize its strategic goals.

The international practice shows that small states usually choose neutrality in order to balance between two confronting great powers. In addition, economic interests of the small state very often lay behind the neutrality strategy - the small state seeks to get economic benefits from the cooperation with both powers, so it is interested in eliminating security policy issues from the bilateral cooperation agenda. In this context it is worth mentioning that Moldova's neutrality strategy from the very beginning has not been the strategy of "balancing", but rather the strategy of "inaction".

The breakout of the critics towards Moldova's security strategy in the state's academic discourse could be observed in 2005, when EU membership 
became the country's strategic goal. Numerous publications in this field belong to Moldova's think tanks - IDIS Viitorul, Association for Foreign Policy (Asociatia pentru Politică Externă), Pro-Marshall Center of the Republic of Moldova (Centrul Pro Marshall din Republica Moldova), NATO Information and Documentation Center of the Republic of Moldova (Centrul informare şi documentare privind NATO din Moldova). Nevertheless, the efforts to reconsider options of security strategy in practice have still been vague.

First, the tendency towards another extreme - alliance security strategy and NATO membership - could be observed in Moldova's academic community. In this regard, the study of IDIS Viitorul experts "In NATO We Trust? Explaining Why Moldova Would Need to Join NATO" should be mentioned. Moreover, in the publications of Moldova's security experts, attention is focused on the issue of the country's partners in the international arena, but not on the wider issue of security strategy. In other words, they try to answer the question "With whom?", but not "How?". Moreover, the relationship between academic thought and political practice in Moldova has been weak, so positive developments in the field of the country's security policy were hardly expected.

The goal of the research presented in this article, is to answer the question, why Moldova chose permanent neutrality and what are the perspectives of this security strategy. In the first part of the article, the relation of Moldova's geopolitical situation with the country's security strategy is discussed. In the second part, based on the analysis of Moldova's strategic documents, the development of Moldova's security strategy is presented and the peculiarities of country's neutrality are discussed. The third part of the article discusses why Moldova until now has upheld its paradox neutrality. Looking from the perspective of three approaches of international relations - realism, pluralism and constructivism, the origins of the demand for neutrality strategy, the emergence of its insufficiency in practice and the perspectives of Moldova's security agenda are analyzed.

\section{Moldova at the Geopolitical Crossroad}

Moldova, which proclaimed it's independence after the end of the Cold War, together with other post-communist states found itself in the so-called "grey zone", described by the "vacuum of power" in relations to the great powers.

Moldova, together with the other countries from the "grey zone", fulfils the function of barrier in the geopolitical codes of the great powers (USA and Russia $)^{4}$. Therefore, looking from the regional perspective, Moldova's geopolitical function depends on the geopolitical function of Ukraine - geopolitical

\footnotetext{
${ }^{4}$ Serebrian O., "Perspectivele geostrategice ale Republicii Moldova" ["Geostrategic Perspectives of the Republic of Moldova"] in Studii internaționale: Viziuni din Moldova. Publicație periodică ştințifico-metodică, Nr. 3(4), 2007, p. 34 (in Romanian).
} 
centre of Eastern Europe. For the Western powers (primarily - USA) Moldova plays the role of "jumping-off ground" for expanding and consolidating the influence in Ukraine. In other words, the existence of strong democratic Moldova would facilitate the democratization of Ukraine. At the same time, looking from Russia's perspective, Moldova is a barrier, blocking Western influence for Ukraine - stable pro-Russian Moldova's geopolitical orientation would assist Russia in "returning" Ukraine to its "sphere of influence".

On 27 August 1991, when declaring its independence, Moldova had not considered the option of remaining within Russia's sphere of influence. Conversely, the goal of a young state was to return to the "historical truth" and restore close relations with Romania, or, even more, to form a common state. This would be the favourable scenario for the West, especially for the USA, because a shift of Moldova's foreign policy priorities towards Romania would "divide" the post-soviet space, and would aggravate the restoration of Russia's influence in the so-called "grey zone". But Russia had not accepted the fact of a loss of influence to its former allies. After Moldova's unsuccessful conflict with Transnistria, provoked by Russia, the latter has diverted Moldova's geopolitical orientation vector from the West towards former Soviet Union space for a long time.

Moldova maintained a "forced" pro-Russian geopolitical orientation for more than a decade. The shift of the geopolitical vector is reflected also in the domestic policy - from 1994 to 2009 parliamentary elections pro-Romanian political forces never held the majority in the country's legislative ${ }^{5}$, and in 2001 the Communist Party with openly pro-Russian programme won the election ${ }^{6}$.

In 2005 Moldova turned to the path of "balancing" between two major powers. Parliamentary election were again won by Communist Party, but this time - with more "pro-Western" programme, naming the EU membership as the strategic goal for Moldova. Nevertheless, in practice, a Communists' EU policy was implemented in a quite formalistic manner ${ }^{7}$, at the same time geopolitical orientation vector fluctuated between Russia and the West. After the early parliamentary elections, which took place on 29 July 2009, four proEuropean parties got the majority in country's legislative (they have formed the alliance "For European Integration"), and Moldova firmly turned towards pro-Western orientation.

At the global level, nevertheless Moldova still remains in "grey zone" between Russia and the West, the country already has institutionalized instruments of cooperation with the West: Moldova is included into the EU Eastern

\footnotetext{
${ }_{5}^{5}$ Josanu Y., Juc V., Rusandu I., Sisteme politice tranzitorii din Europa de Sud-Est (studiu comparat) ["Political Systems in Transition in South-Eastern Europe (Comparative Study)"], Chişinău, 2008, p. 77 (in Romanian).

${ }^{6}$ Waters T., The "Moldovan Syndrome" and Re-Rusification of Moldova: Forward into the Past!", G105, Conflict Studies Research Centre, February 2002, p. 3-4.

${ }^{7}$ Molodilo D., "Republic of Moldova within the European Security System: Partners, Challenges, Perspectives" in European and NATO Neighbouring policies - new dimensions for regional cooperation, training seminar, Chisinau, Republic of Moldova, November 28-29, 2007, p. 87.
} 
Partnership Initiative, in the nearest future the negotiations with the EU on the EU-Moldova Association agreement will start, Moldova cooperates with NATO under the Individual Partnership Action Plan.

Regional context is also favourable for the strengthening of Moldova's pro-Western orientation: Moldova expeditiously improves relations with EU and NATO member Romania, another neighbour of Moldova - Ukraine, is also aspiring for EU integration. Moldova's participation in the Black Sea region cooperation formats also support the spread of democratic and pro-Western values and strengthens the aspirations of euro integration. Even in the postsoviet sphere Moldova belongs to the so-called pro-Western formation - the GUAM block, including Georgia, Ukraine, Azerbaijan and Moldova.

In the local level Moldova encounters the greatest challenges and obstacles to the maintenance of its pro-Western orientation. Firstly, a frozen conflict with Transnistria is the main reason for the maintenance of Russia's strong influence for Moldova. As it is mentioned by experts, after the "freezing" of the Transnistrian conflict Moldova became the state with two governments, two flags, and, what is worst of all, two armies ${ }^{8}$. Moreover, if the frozen Transnistrian conflict would pass to the "hot" stage, what happened to Georgia in 2008, the real threat to Moldova's sovereignty, or at least for loosing "all the work it has done" in cooperation with the West, would arise. Second, the development of pro-Western Moldova's orientation has been restrained by difficult country's demographic situation. Moldova has been experiencing one of the greatest flows of the economic migration in the context of post-soviet space. According to the official data of research, carried out in 2004, about 600 thousand citizens out of Moldova's labour force, or every third employable Moldovan, is working abroad $^{9}$. According to experts, the real number of economic emigrants could be to two times higher. In this context, the critical pro-Western part of society is being "dissolved", at the same time there are favourable conditions inside the country for the concentration of critical "volume" of citizens, who stand for the firm relations with Russia.

\section{The Development of Moldova's Security Strategy}

A complicated security situation and Moldova's difficult political and economic transition in the early 90 's prompted the country to choose neutrality as a compromise security strategy. Thus, the decision to adopt neutrality was

\footnotetext{
${ }^{8}$ King Ch., The Moldovans. Romania, Russia and the Politics of Culture. Stanford University, 2000, p. 229.

${ }^{9}$ Мошняга В., “Международная трудовая миграция молдавского населения и проблема денежных переводов в человеческом и институциональном измерении"' “International Labour Migration of the Moldova's Inhabitants and the Problem of Monetary Transactions from the Human and Institutional Perspectives"] in Studii internaționale:Viziuni din Moldova. Publicație periodică şstințifico-metodică, Nr. 4(5), 2007, p. 23 (in Russian).
} 
precipitous and un-weighted, misevaluating internal and external situation of the country. First and foremost, Moldova, from the very start, has not corresponded even minimal requirements for a neutral country. Moreover, Moldova's neutrality has not been guaranteed by any other external power (country or international organization) and has not been recognized by the international community. The paradox is that now Moldova's neutrality has become a kind of "axiom" of state's security policy, the relevance and expedience of which does not appear under considerations in the political debates.

\subsection{The Development of Security Policy in the Strategic Documents}

The security strategy of a sovereign state - complex formation that describes the behaviour of the state, which seeks to guarantee its security, taking into account internal and external threats. So, security strategy involves both strategic documents and the country's day-to-day political practice. It is important to mention that nevertheless, the country's security policy directions are not always fixed in the strategic documents, the "documentation" of the state's security policy is important for several reasons. Firstly, by involving the main principles of the state's security policy in the strategic documents, the country informs other members of the international community about its intentions in the field of foreign and security policy. Secondly, strategic documents help to maintain the continuality of a state's foreign and security policy, which is especially important during the change of ruling elites.

Moldova, comparing to other post-communist states, formed the full hierarchy of its strategic documents quite early. The Concept of National Security, which is being considered as a "core" strategic document, was adopted in 1995 (the new edition of this document was adopted by the Parliament in May 2008), Concept of Foreign Policy, which is still acting, was also adopted in 1995. That same year the Military Doctrine was approved. Although having a "classical" form, Moldova's system of strategic documents lacks the accordance with actual geopolitical and security situation.

The first document of independent Moldova - the Declaration of Independence, which was adopted on 27 August 1991, has no reference to the state's neutrality. Moreover, the document emphasizes the importance for Moldova to become a part of the universal and specialized regional international organizations, stressing the importance of Moldova's participation in the Conference for Security and Cooperation in Europe (the predecessor of contemporary OSCE) and active participation in its mechanisms ${ }^{10}$.

The tone of Moldova's Constitution, adopted in 1994, was completely different from the tone of the Declaration of Independence $-11^{\text {th }}$ Article of the

\footnotetext{
${ }^{10}$ Lege privind Declarația de Independență a Republicii Moldova [The Law on the Independence Declaration of the Republic of Moldova], Nr.691-XII din 27.08.91, Monitorul Oficial al R. Moldova nr.11-12/103 din 30.12.1991 (in Romanian).
} 
Constitution foresees the permanent neutrality of Republic of Moldova ${ }^{11}$. The declaration of neutrality in the Constitution is a very strong assertion of security policy, from which it is difficult to step back both politically and technically. In addition, it is worth paying attention to the fact, that neutrality was declared by a young, newly-independent state, foreign and security policy directions of which yet had been only in the process of formation.

The Concept of National Security of 1995, the main strategic document, repeated the constitutional provision of the permanent neutrality ${ }^{12}$ without further explanations. In this document, great attention was paid towards internal threats to Moldova's security (attempt against country's constitutional order, the provocation of social unrest, the reduction of country's economic, technological and defensive capabilities and etc.). At the same time external threats are formulated in a quite abstract manner and seem to be automatically rewritten form the "sample" security documents. For example, the threat of terrorism, which was not so actual for the Moldova in mid-90's, is described by a separate point in the document, at the same time the threat caused by the $14^{\text {th }}$ Russian army, dislocated in Moldova's territory after the unsuccessful conflict with Transnistria, was described by loose formulation "the threat of direct aggression against Moldova's territory", and the most actual threat for Moldova - separatism threat - is not even mentioned, replacing it with "the threat of conflicts in Moldova's international environment".

The improvements of the Concept of National Security should have taken place in 1998, but because of the Russian crisis, which had especially grave consequences for the Moldova, dependent from Russia's markets, this task was postponed ${ }^{13}$.

At the end of 2005 the then president Vladimir Voronin ordered by the decree to form two commissions to improve the Concept of National Security and the Concept of Foreign Policy ${ }^{14}$. In May 2008 the Parliament approved a new edition of the Concept of National Security. In comparison with its predecessor, the new document is more concrete, putting emphasis on external more that internal threats, the first place in the list of threats belongs to the

\footnotetext{
${ }^{11}$ Constituția Republicii Moldova [The Constitution of the Republic of Moldova], http://www.presedinte. $\mathrm{md} /$ const.php?page=8100\&lang=rom $\# 8100$ [2009-11-15] (in Romanian).

${ }^{12}$ Hotarirea Parlamentului Republicii Moldova cu privire la aprobarea Concepției securității naționale a Republicii Moldova şi la formarea Consiliului coordonator pentru elaborarea proiectelor de legi şi altor acte normative care vor reglementa construcția, pregătirea şi folosirea Forțelor Armate [The Decision of the Parliament of the Republic of Moldova on the Formation of Coordination Council for the Preparation of the Projects of the Laws and Other Normative Acts, which will Regulate Formation, Training and Use of the Armed Forces], Nr.445-XIII din 05.05.95, Monitorul Oficial al R. Moldova nr.35/399 din 29.06.1995 (in Romanian).

${ }^{13}$ Mînzărari D., Proiectul Concepției securității naționale - test decisiv pentru elita politică moldovenească [The Project of the National Security Concept - Crucial Test for the Moldovan Political Elite], Discussion paper No. 1 August 2007, IDIS Viitorul, p. 14 (in Romanian).

${ }^{14}$ Leşanu A., "Concepția Securității naționale: un document strategic pentru scopuri tactice" ["National Security Concept: the Strategic Document for Tactical Aims] in Political and Security Statewatch, Buletin analitic lunar de IDIS Viitorul, Mai 2008 Nr. 5 (12), p. 9 (in Romanian).
} 
Transnistrian conflict and the threat to Moldova's territorial integrity. Nevertheless, the main shortcomings of the previous Concept of National Security were not corrected.

Firstly, the new document was already criticized because of the form. The Concept of Moldova's National Security foresees that, on the ground of this document, National Security Strategy will be prepared, which will foresee the ways for guaranteeing country's security, mechanisms, the financing of security and defence sectors and the reformation of security sector ${ }^{15}$. It could be interesting why the document, adopted in May 2008, could not cover these aspects. As international practice shows, the guiding document in the security field could be formulated both as concept and as strategy. If the form of conception was considered to be inappropriate for settling of goals and means to maintain national security, it is still unclear, why Moldova's Government, instead of preparing second Concept of National Security, had not followed with the preparation of National Security Strategy at this time.

It is observed that post-soviet states tend to label the core document in the security sphere as the concept in order to "soften" the character of the document ${ }^{16}$. In the case of Moldova, even though during the discussion period it was proposed to formulate the document as strategy, not concept, but, most probably, seeing to avoid the Russia's reaction, this proposal was not taken into consideration.

Secondly, the Concept of National Security overtook the shortcomings of the content from its predecessor. The document overtakes, but doesn't explain or develop, the principle of neutrality, only complementing it with the principle, that Moldova cannot become the member of military alliances. When speaking about Moldova's position in international arena, the Concept of National Security simultaneously foresees both euro integration and strengthening the relations with the CIS. It is obvious that these two goals are incompatible and neutralize each other ${ }^{17}$. Moreover, considering cooperation with NATO, it is emphasized that Moldova doesn't seek NATO membership. Obviously, it is not necessary to state it separately, because Moldova's relations with military alliances (not only NATO) are described by the principle of neutrality. Otherwise, the emphasis on NATO could make a negative impact on Moldova's cooperation with Alliance in the future.

Thirdly, after the approval of the new Concept of National Security, the Concept of Foreign Policy remained unchanged (nevertheless the project of the

\footnotetext{
${ }^{15}$ Lege Nr. 112 din 22.05.2008 pentru aprobarea Concepției securității naționale a Republicii Moldova, [Law No. 112 of 22 May 2008 for the Approval of the National Security Concept of the Republic of Moldova], Publicat : 03.06.2008 în Monitorul Oficial Nr. 97-98 art Nr : 357 (in Romanian).

${ }^{16}$ Mînzărari D., Proiectul Concepției securității naționale - test decisiv pentru elita politică moldovenească (note 13), p. 6.

${ }^{17}$ Grosu V., "Considerații privind Contepția securității naționale a Republicii Moldova" ["Considerations in respect of National Security Concept of the Republic of Moldova], Securitatea naționala - imperativ strategic, Jurnal academic Mai 2008, ediția 9, Centrul informare şi documentare privind NATO din Moldova, p. 12 (in Romanian).
} 
new Concept of Foreign Policy was prepared). So, now Moldova's foreign policy priorities are foreseen by the 1995 document, which nowadays is completely out of date and doesn't accord current international and regional situation. In 1995, when the Concept of Foreign Policy was adopted, EU integration was not on the list of Moldova's priorities, so the document foresees more realistic priority for that time - integration into the $\mathrm{CIS}^{18}$. So, now Concept of National Security foresees EU integration, at the same time Concept of Foreign Policy country's integration into the CIS. The problem of incompatibility of strategic documents makes both documents only formal, leaving Moldova's security policy without firm ground.

Small states, acting in the international arena, often intend to minimize possible risks, not to maximize the winnings ${ }^{19}$. This aspect of behaviour determines cautious, reactive foreign policy of a small state. But in the case of Moldova, the developments of the geopolitical situation and the country's geopolitical orientation are being reflected in the practical foreign policy only, separating security policy from these processes. As a consequence, Moldova's security strategy, formulated in 1994-1995, remains "frozen".

The paradox of Moldova's security policy is determined by the fact that country's strategic documents were adopted primarily seeking to "inform" external players (first of all - Russia) about the directions of country's security policy, but eventually these documents became a "permanent bra$\mathrm{ke}^{\prime \prime}$, preventing the country form the possibility to choose more relevant and well-balanced security strategy. In this way, Moldova's security strategy has become "trapped".

\subsection{The Problems of Permanent Neutrality}

One of the most actual and most discussed issues of Moldova's security policy - declared permanent neutrality.

Moldova's security strategy from the very start has not been the independent choice, but rather the consequence of the "neutralization" of the country $^{20}$. On 27 August 1991 Moldova declared its independence, after what it was expected, in the case of optimistic scenario - reunification with Romania, in the case of realistic scenario - close ties with the neighbour. Russia was frightened of losing a former partner and made every effort to turn Moldova to at least the path of neutrality. The strongest card Russia held was the conflict with Transnistria, which broke out in the fall of 1990 and has not been resolved yet. Russia interfered in the conflict by deploying its military forces in the

\footnotetext{
${ }^{18}$ Munteanu I. et al, 100 cele mai presante probleme ale Republicii Moldova in 2006 [100 Key Problems of the Republic of Moldova in 2006], Studiu de analiză, IDIS Viitorul, Chişinău, 2006, p. 187 (in Romanian).

${ }^{19}$ Handel M. I., Weak States in the International System. London: Frank Cass, 1970, p. 52-53.

${ }^{20}$ Mînzărari D., Proiectul Concepției securității naționale - test decisiv pentru elita politică moldovenească (note 13), p. 43.
} 
Transnistria, which de jure is a part of Moldova. So, in 1994, when adopting the Constitution, the first document to officially declare the status of neutrality, Moldova had a breakaway region with the military forces of foreign country, dislocated in it. The refusal from neutrality at that time could determine both the use of Russia's armed forces and final separation of Transnistria from Moldova. Reacting to this situation, Moldova overtook declarative neutrality.

Thus in the beginning of the 1990's, Moldova's Government had several reasons to declare neutrality (declare, not choose, because Moldova has never been neutral country by the definition). First of all, a declared neutrality made it possible for Moldova, despite growing pressure, to remain outside the Russiadominated security and military structures, such as Collective Security Treaty Organization $^{21}$. Moldova became the member of CIS in 1991, mainly striving to maintain mutually beneficial economic and social ties with other post-soviet states. Nevertheless, Moldova avoided cooperation in foreign policy and security fields in the context of CIS. In 1993, Moldova, together with Georgia and Azerbaijan, signed CIS Articles of Agreement with the exception to cooperation in military-political dimension ${ }^{22}$. Thus, Russia's pressure for Moldova to join the CSTO has been felt up until now ${ }^{23}$.

Second, a Constitution of the Republic of Moldova has been adopted already after the unsuccessful for Chisinau armed conflict with breakaway Transnistria, which took place in summer 1992. Constitutional provision of neutrality was one of the conditions, which facilitated Chisinau's cohabitation both with breakaway Transnistria and with Russia, which deployed its military forces in Moldova's separatist region. Moreover, Moldova's Government hoped that the principle of permanent neutrality, fixed in the main country's law, would prompt Russia for faster demilitarization of Transnistria. Following this logic, if Russia is willing to see Moldova as neutral country, it should respect the basic principles of neutrality, fundamental of which is non-hosting of foreign armed forces in neutral territory.

Third, some experts claim that neutrality allows country to save on the expense of defence sector, not developing strong armed forces ${ }^{24}$. This approach is supported by the insight that a strong army is not enough for the state to maintain its national security in the contemporary international system ${ }^{25}$. So, the resources, saved on the expenses of "hard" security sector, could be redistributed to other important sectors, enhancing "soft" security and at the same time avoiding so-called "security dilemma".

\footnotetext{
${ }^{21}$ Marandici I., "Moldova's Neutrality: What is at Stake?" in Quo Vadis, Moldova?, Lviv: Multi-M, 2007, p. 47.

${ }_{22}^{22}$ Tăbârtă I., Berbeca V., Proiectul CSI: Anatomia unui eşec [The CSI Project - Anatomy of One Failure], Politice publice Nr. 7 2009, IDIS Viitorul, 9 (in Romanian).

${ }^{23}$ Molodilo D. (note 7), p. 90.

${ }^{24}$ Cebotari S., Saca V., "Republica Moldova între statutul de neutralitatea şi aderarea la NATO" ["The Republic of Moldova Between Status of Neutrality and the Perspective of NATO Membership"] in Studii internationale: viziuni din Moldova. Publicație periodică ștințifico-metodică, Nr. 3(4), 2007, p. 68 (in Romanian).

${ }^{25}$ Gorincioi R., "Developing National Security Concept and Strategy: Assessing Existing Needs and Risks" in European and NATO Neighbouring Policies -New Dimensions for Rregional Ccooperation, Training Seminar, Chisinau, Republic of Moldova, November 28-29, 2007, p. 52.
} 
Nevertheless states that choose neutrality as their security strategy seek more flexibility and a wider manoeuvre space in other spheres, the neutrality strategy is very rigid in regard to country's security policy. In the security policy field, neutrality limits the area for state's actions to its national borders. In other words, neutrality minimizes the possibilities for a small state to search for "external sources of security". So, in the case of Moldova, a precipitous decision on neutrality raises several problems.

Firstly, the neutrality should be not only declared by the particular state unilaterally, but also recognized by international community. Other states (or other subjects of international relations) should perceive the particular state as neutral. It is also worth mentioning that in the contemporary international arena neutrality in its pure form is very rare security strategy. Either historically neutral states (for example, Switzerland) or states that are balancing between great powers by the help of economic resources (for example, Azerbaijan) are usually perceived as neutral. At the same time Moldova has never been perceived as neutral ${ }^{26}$ by the actors of the international community. Moreover, Russia intends to violate Moldova's neutrality by deploying its military forces in the country's jurisdiction. Due to this, unilaterally declared Moldova's neutrality performs only as guidelines for country's security policy at best, but not as a real security strategy, aiming to guarantee the security of small state.

Secondly, the security of the state, situated in the zone of high geopolitical tension, should be guaranteed by the "external" source of security - state or the group of states, providing security guarantees for a small state ${ }^{27}$. The neutrality of small state also should be supported "from the outside", by formal or informal mechanisms. But the neutrality of Moldova fails to have any "external" guarantees, neither formal, nor informal ${ }^{28}$. In addition, the status of neutrality restricts Moldova's external cooperation in the field of security.

Thirdly, Moldova's neutrality strategy fails to fulfil its main function - to guarantee the country's security. Adversely, the neutrality adds to the "conservation" of the situation of insecurity. After Russia deployed its military forces in separatist Transnistria, Moldova has not only been unable to press de facto authorities in Tiraspol for faster conflict resolution, but also to search for assistance on this issue outside its borders. As it already has been mentioned, Moldova encounters the greatest threat to its national security at the local level. Due to this neutrality, which is designed to help the state avoid being in high geopolitical tension, in Moldova's case is not an optimal security strategy.

Fourthly, Moldova's declared neutrality slows down the process of

\footnotetext{
${ }^{26}$ Mocanu Gh., 100 cele mai presante probleme ale Republicii Moldova in 2008 [100 the Most Presented Problems in the Republic of Moldova in 2008], IDIS Viitorul, Chișinău, 2009, p.243 (in Romanian).

${ }^{27}$ Spiegel S., Dominance and Diversity. The International Hierarchy. Boston, 1972, p. 133, 136. From: Amstrup N., "The Perennial Problems of Small States: a Study of Research Efforts", Cooperation and Conflict. Nordic Journal of International Studies. Vol IX, No. 3, 1976, p. 170.

${ }^{28}$ Munteanu I. et al, Moldova pe calea democrației şsi stabilității din spațiul post-sovietic în lumea valorilor democratice [Moldova on the Path of Democracy and Stability in the Post-Soviet Space in the Contex t of Democratic Values], IDIS Viitorul, 2005, p. 247 (in Romanian).
} 
reforming and developing country's armed forces. The principle of permanent neutrality, nevertheless fixed in the Constitution, is not explained in the strategic documents. Vague country's security strategy fundament indicates that Moldova's politicians, when adopting the principle of neutrality, had obscure vision what the neutrality is about how it should function in the case of Moldova. For this reason, the situation within country's armed forces, inherited from the Soviet period, have been frozen, and the necessary reforms have been delayed ${ }^{29}$. These circumstances lead to the weakening of the country both in external (as a reliable partner in international arena) and internal security dimensions.

Moreover, the function of country's security strategy is not only to guarantee the maintenance of the statehood, but also to facilitate to the realization of national interests ${ }^{30}$. On the one hand, the weak articulation of Moldova's national interests - one of the reasons, why the country failed to choose more efficient security strategy and has been forced to stick to the declarative neutrality. On the other hand, the neutrality strategy has been blocking the review of country's national priorities. So, Moldova has appeared inside "closed circle" - the state fails to review its national interests because it is forced to stick to the declared neutrality.

So, it is obvious that the declarative neutrality not only hasn't improved the country's security situation, but also may lead to its deterioration. The Constitutional provision of neutrality could be abandoned only by referendum (The Constitution of the Republic of Moldova, Article 142, Part 1) ${ }^{31}$. Public opinion surveys show that majority of Moldova's citizens (in November 2009 - 58.8 percent) are in favour of neutrality as a strategy, capable to guarantee Moldova's security $^{32}$.

The demand for neutrality in Moldovan society could be explained by several factors. First of all, Moldova's society in early 1990's experienced armed conflict with the breakaway Transnistria nevertheless the conflict itself was not of a high intensity, people hope that neutrality would prevent them from another armed conflict in the future. In other words, Moldovan society accepts the neutrality security strategy not because of its capability to improve the security situation, but because it could add to the stability of the current security situation, preventing it from possible further deterioration. Second, the early transition period of the independent Moldova, which coincided with the pro-Romanian political moods, terminated in the disappointment of the majority of citizens, especially - in economic and social fields. So, a part of

\footnotetext{
${ }^{29}$ Busuncean T., "Controlul democratic asupra reformei sectorului de securitate în Republica Moldova" ["Democratic Control on the Reforms of Security Sector in the Republic of Moldova"] in Studii Internationale: Viziuni din Moldova. Publicație periodică ştinţifico-metodică, Nr. 3(4), 2007, p. 55-56 (in Romanian).

${ }^{30}$ Gorincioi R., "Developing National Security Concept and Strategy: Assessing Existing Needs and Risks" (note 15), p. 57, 59.

${ }^{31}$ Constituția Republicii Moldova (note 11).

${ }^{32}$ Barometrul Opiniei Publice, Republica Moldova, Noiembre 2009 [Barometer of Public Opinion, the Republic of Moldova, November 2009], Institutul de Politice Publice, p. 110. From http://www.ipp.md/files/ Barometru/2009/final_bop_noiembrie_2009_recap.pdf [2009-12-21] (in Romanian).
} 
Moldova's society perceive neutrality as a "check" from the failures of proRomanian policy in the future.

Moldova's neutrality simultaneously suffers from two major shortcomings - it is both inadequately chosen and inappropriately implemented.

In the case of inadequate choice, the paradox is that the state sacrifices more in the field of security policy than gets "in return". This situation could be named as "a pure loss", which has negative impact not only for security sphere, but also for other spheres (for example, foreign policy). Moreover, this unhealthy situation may lead to the decrease of state's structural power.

Inappropriate implementation of the Moldova's neutrality strategy includes several factors: external, which do not depend directly on Moldova (frozen Transnistrian conflict, Russia's military presence in Moldova), and internal (Moldova's Government perceives neutrality not as balancing, but as inaction). If Moldova's government would change its attitude towards neutrality - this means to perceive that neutrality also could be implemented actively, there would be a possibility that external factors would be reduced in time.

The creation of the basic conditions for Moldova's neutrality to function could minimize the threats to the country's security (negative goal of the security strategy). Nevertheless, appropriate implementation of neutrality strategy doesn't solve the problem of inappropriate choice. Even if Moldova's neutrality would function well, finally it would be "goal for itself". This would restrict the development of country's structural power (positive goal of the security strategy).

\section{Factors of Moldova's Neutrality}

The neutrality strategy, applied by Moldova, has been raising more security challenges then providing solutions. Although it could be said that both the adoption of declarative neutrality in early 1990's and maintenance of it have been rather the outcome of the specifics of the Moldova's domestic and external policies issues then their cause. In other words, Moldova's choice (even if it has been not optimal) to implement a particular security strategy was anticipated by the number of factors of various intensity.

The problem of permanent insecurity of a small state and the efforts to defend its security are closely connected with the external factor. Due to the high level of vulnerability the small state depends of international conjuncture. Although the final decisions in the sphere of security policy belongs to the small state itself, nevertheless the configuration of great powers in the international arena implies several restrictions on the choices, available for small state.

The sources of Moldova's neutrality are analyzed from the perspective of three approaches of international relations - realism, pluralism and constructivism. 


\subsection{Identity Crisis and the Problem of Political Choice for Moldova}

Analyzing the choice of the neutrality strategy from the perspective of constructivism, the key factor, determining the choice of neutrality and it's maintenance for Moldova - country's balancing between pro-Romanian and pro-Moldovan political identities.

A sophisticated and ambiguous history of Moldova ${ }^{33}$, soviet "heritage" and fragmentary identity policy of newly independent Moldova led to the deep cleavage in Moldova's political identity - since the restoration of independence concepts of Romanian and Moldovan state identities have been confronting.

Struggle for Moldova's independence started from the ethnic Romanian movement. On 27 August 1989 ethnic-intellectual movement - Great Assembly (rom. Adunarii Mare) - started. During the Great Assembly, which converted to several days' of protest, the following demands were formulated: the legal status for Romanian language as a state language, sovereignty for Moldova and the adoption of new Constitution. On 31 August 1989, after a very tense sitting of Supreme Council of Moldova Soviet Socialistic Republic, then chairman of Supreme Council Mircea Snegur (after the restoration of independence he became the first president of Moldova) declared Romanian language an official language of the Moldova Soviet Socialistic Republic. In the Declaration of Independence, adopted after almost two years (27 August 1991), the reference to the decision to announce Romanian as state language is made. The tricolour flag of Romania with the Moldova's coat of arms in the middle was adopted as a flag of Moldova, aiming to emphasize the historical brotherhood of both countries. Romania's anthem "Wake up, Romanians!" (rom. "Deşteaptă-te, române!") was chosen as Moldova's anthem ${ }^{34}$.

Similar processes took place in Romania. After the overthrow of authoritarian regime of Nicolae Ceauşescu, Romanians cherished hopes for restoration of "historical truth" and widely supported Moldova, which split from the Soviet bloc. Romania was the first state to recognize a newly independent Moldova and to establish diplomatic relations - the first embassy in Chisinau

\footnotetext{
${ }^{33}$ The Moldova's principality formed in mid-XIV ct., about the same time organized entities in Wallachia and Transilvania emerged. In XVI ct. those three regions, inhabited by ethnic Romanians, set first personal union. In 1859, also through the common ruler, two Romanian lands - Wallachia and Western Moldova unified, forming the nucleus of modern Romania. New state in 1881 was oficially named Romania. Bessarabia - the territory between rivers Prut and Dniestr, almost coinciding with the territory of contemporary Moldova (exept Transnistria), since 1812 had been occupied by Russian Empire. At this time difference between denominations "Moldova", historical territory, which included Bessarabia and Western Moldova (territory between Prut river and Carpatian Mountains, now - Eastern Romania) and "Bessarabia" (territory between Prut and Dniestr rivers, inhabited by ethnic Romanians) formed. At the begining of 1918 Bessarabia proclaimed it's independence and declared the unification with Romania. Statehood of Romania, including Bessarabia, lasted till 1940.

${ }^{34}$ Caşu I., "Politici identificare în Moldova sovietică şi post-sovietică" ["The Identity Policies in Soviet and Post-Soviet Moldova"], RO-MD/Moldova în două scenarii, Centrul pentru artă contemporară, Chişinău, 2008, p. 67 (in Romanian).
} 
was Romania's ${ }^{35}$. So, Moldova had a strong partner in the international arena from the very beginning of its independence.

In the early 1990's, the international community including Romania itself, treated Moldova's independence as an interim stage towards the reunification with Romania. Thus due to the odds, which showed up later, Moldova had been willing more and more to maintain its statehood. Soon brotherhood with Romania had been gradually changed with tension, which than grew to hostility, and pro-Romanian identity was replaced by pro-Moldavian one.

The existence of a so-called pro-Moldavian identity was the result of half a century of soviet propaganda. The political authorities of USSR aimed to antagonize Romania in relation to Moldova to the greatest possible extent. The core instrument had been the neglect of Moldova's inhabitants' identity as Romanians. Moreover, soviet authorities made huge efforts to create "scientific approval" of the existence of Moldovan ethnos, as separate and different from Romanian ethnicity. To be exact, the historical sources provide reference to the denomination "Moldovan", but, according to the historians, it is the reference to the territorial, not ethnical relation - "Moldovan" was the denomination of Romanian, living in the Principality of Moldova ${ }^{36}$.

Soviet moldavists aimed to prove that Moldovans are culturally and linguistically different from Romanians and have their own historical destiny. To facilitate the realization of this goal, artificial Moldovan language was created: Romanian language, rewritten in Cyrillic alphabet, was denominated as Moldovan. Moreover, the citizen of Soviet Moldova was free to identify himself with any nationality - Moldavian, Russian, Ukrainian, Jewish, Gaguz, but no way with Romanian. Declaration in publicity that you are Romanian, threatened with penal case for the provocation of nationalism or even action against territorial integrity of Moldova SSR. Charges could be brought also for the "too correct" usage of the (Romanian) language. ${ }^{37}$

Soviet-indoctrinated Moldovan identity revived in 1994. In the Constitution, adopted the same year, inexistent Moldovan has been foreseen as the state language. By this move, Moldovan politicians aimed to emphasize Moldova as separate from Romania. Moreover, in the same 1994 the decision to change the national anthem was taken - "Wake up, Romanians!" was replaced by the lyrics of Alexander Mateevici "Our language" (rom. "Limba noastră"). The image of Romania as a rival force, dangerous for Moldova's sovereignty, was maintained till 2005. The refusal of Romanian identity was stimulated also by economic hardships: in 1994 Moldova suffered unprecedented economic decline, when country's GNP, in comparison with 1989, decreased by 50 per cent. Just after several years - in 1998 - Moldova felt the grave consequence

\footnotetext{
${ }^{35}$ Josanu Y. et.al. (note 5), p. 84.

${ }^{36}$ Timpul, Pâslariuc V., "650 ani ai "statalitătii moldoveneşti", proiect al elitelor "bugetovore"” ["650 years of Moldova's Statehood: the Project of "Suppliant" Elites"], Interviul de luni, 23 February 2009 (in Romanian).

${ }^{37}$ Casu I. (note 34), p. 64.
} 
of Russia's economic crisis. On the one hand, at the period of huge economic decline people usually don't give priority to the identity issues. On the other hand, at the time of economic decrease politicians in populist style used the allusion to "wealthy soviet era", which raised the number of supporters of pro-Moldova identity. Also Russia's factor was influential for abandoning pro-Romanian identity.

In 2005, EU integration became a strategic goal of Moldova, so the then ruling Communist Party was forced to soften its tone in relation with Romania. Nevertheless, relations with Romania remained strained, and communists further escalated negative image of Romania inside Moldova. The tension in bilateral relations reached its peak after the April 2009 parliamentary elections, when communists accused Romania of staging the massive protests. After these protests communists government introduced visa regime for the citizens of Romania.

Simultaneously an adverse process could be observed in Moldovan society: after 2003, when Moldova lifted its ban on dual citizenship, over one million of Moldovans expressed their willingness to obtain Romanian citizenship. Till now about 120 thousand of Moldovans are already granted with Romanian passports.

The new stage of Moldovan-Romanian relations took place after the July 2009 early parliament elections, which, by a tight overweight ${ }^{38}$, were won by former opposition parties, which formed the alliance "For European Integration". The new pro-Romania government immediately lifted all the sanctions, introduced to Romania by communist government, and turned the political wheel towards closer relations with the latter. Prime Minister Vlad Filat during his first official visit in Brussels declared that his mother tongue is Romanian ${ }^{39}$. This was the first official declaration of this type since 1994. At the end of 2009 Moldova's state institutions amended their websites, changing the option of Moldovan language (MD) to Romanian (RO) in the language options bar ${ }^{40}$. Romania, on its side, declared the readiness to significantly increase the level of granting the citizenships to Bessarabians - starting from 2010, it is planned to grant 100 thousand Romanian passports to Bessarabians annually ${ }^{41}$.

Due to the absence of a stable political identity, Moldova's security policy has been hanging between the West (primarily - Romania, also - EU and NATO) and the East (primarily - Russia and Russian-dominates CIS area). As it has been well noticed by historian Charles King, in the early 1990's Romanians

\footnotetext{
${ }^{38}$ The four-parties post-electoral alliance "For European Integration" gained 53 seats in 101-seat parliament, Communist party -48 mandates.

${ }^{39}$ Radio Free Europe/Radio Liberty, Moldovan Premier Wants “Clear EU Perspective”, Financial Aid, 30 September 2009.

${ }^{40}$ Radio Free Europe/Radio Liberty, Moldovan Government Switches to "Romanian" Language on Websites, 28 October 2009.

${ }^{41}$ Rodkiewicz W., From "Virtual" to European Democracy - the Origins and Consequences of the Political Breakthrough in Moldova, Centre for Eastern Studies, Warsaw, December 2009, p. 79
} 
of Bessarabia woke up, but forgot to get out of the bed ${ }^{42}$. This situation led the country towards a neutrality security strategy, which is the political reflection of fluster between two competing identities.

Geopolitically Moldova has no concrete dependence to a particular region. So, identity becomes the key factor, defining the "target" region (SouthEastern Europe, Black sea Region, Eastern Europe, CIS space). The choice on the region, to which Moldova would prefer to belong, would facilitate first, to identify the potential external sources of security, in regard to which Moldova should orientate its security policy, and second, it would help to define the threats and to design the options for their minimization.

\subsection{Permanent Neutrality as Moldova's "Neutralization"}

Moldova's identity, deeply polarized during the Soviet period, gave the impetus for the Transnistrian conflict to arise. The latter soon was frozen and became the hugest threat to Moldova's national security.

Looking from the perspective of realistic approach, Moldova, from the very start of its statehood, encounters the permanent hard security threat. Moreover, this threat is of highest intensity - the threat to state's territorial integrity. After the August 2008 Russian-Georgian war, which created the precedent for "extreme" use of frozen conflict, Moldova's hard security threat became even more dangerous.

\subsubsection{Frozen Conflict with Transnistria - Permanent Threat to Moldova's Security}

Transnistria - a narrow strip of land with about 500 thousand inhabitants, situated on the left bank of river of Dniestr. This territory historically has never belonged to Moldova and was attached to Bessarbia only in Soviet times. In the Soviet era Transnistria became the industrial centre of Moldova: this tiny region produced some 90 percent of electricity, consumed by Moldova SSR, and created about 40 percent of Moldova SSR GDP ${ }^{43}$.

Transnistria was settled by Russian-speakers from all USSR, who have never learned Romanian (then called "Moldovan"). On 31 August 1989, the Supreme Council of Moldova SSR adopted the law, providing the official state language status to Romanian language, after which a wide-range protest started in Transnistria. This transformed into separatist movement. According to experts, protests of Russian-speaking people in Transnistria certainly were

\footnotetext{
${ }^{42}$ King Ch. (note 8), p. 224.

${ }^{43}$ Trilateral Plan for Solving the Transnistrian Issue. Regional Partnership for a Common Commitment Oriented Approach. Policy paper, developed by Moldova-Ukraine-Romania expert group. BucharestChisinau-Kiyv, January 2006, p. 14.
} 
staged, because local inhabitants could hardly give such an immediate reaction to the law on state language $\mathrm{e}^{44}$. Although the Law on the state language became the pretext for a separatist processes in Transnistria to gain speed. Referring to the "fear of Romanian nationalism", on 2 September 1990 de facto Transnistrian Moldavian Republic (TRM) declared the secession from Moldova, elected de facto president (this post for four terms successively has been occupied by Igor Smirnov) and adopted its own Constitution. Moldova hasn't accepted the secession of the region. As a consequence of this in the fall of 1990 in Dubassary and in the spring 1992 in Bendery, bloody clashes occurred between Moldova's forces and Transnistria's de facto forces. In the summer of 1992 Russia sent the $14^{\text {th }}$ Army (reservist military formation) to pacify the upheaval. When the upheaval was pacified, the $14^{\text {th }}$ Army has remained in Transnistria to safeguard Russia's military equipment, left in Transnistria after the disintegration of USSR. In 2000, there was about 42 thousand tons of Russian ammunition. According to OSCE, during 2000-2004 some 50 percent of Russian ammunition left Transnistria (was transported or destroyed at the place) ${ }^{45}$ Currently some 1,500 Russian soldiers and some 20 thousand tons of Russian ammunition are still deployed in Transnistria.

On 21 July 1992 Russia, Moldova and Transnistria signed a Cease-fire agreement. Nevertheless Russia declared acting as a mediator between conflicting Moldova and Transnistria, the participation of Russia in the cease-fire agreement confirms that the real conflicting sides are Russia and Moldova, not Moldova and Transnistria. ${ }^{46}$ Moreover, a cease-fire agreement has programmed one more deadlock. According to this document, Joint peacekeeping forces, consisting of five Russian, three Moldovan and two Transnistrian battalions, were formatted. Joint peacekeeping forces were dislocated in security zone (10 km row along the Dniestr, from both sides of Dniester). But the Cease-fire agreement failed to foresee the deadline, when Joint peacekeeping forces (consisting mainly Russian military forces) should leave the region ${ }^{47}$.

On 21 October 1994 Russia and Moldova signed the agreement on the term and status of Russian military forces in Moldova's territory. By this agreement Russia has taken on the responsibility to withdraw its military forces from Moldova over a three years' period from the moment, when this

\footnotetext{
${ }^{44}$ From the interview with former Minister Counsellor of the Republic of Moldova in Romania dr. Gheorghe Căldare, October 2009, Chisinau.

${ }^{45}$ Asarov B., "Transnistria: riscuri şi provocări militare, politice şi de altă natură" ["Transnistria: risks and provocations of military, political and other origins"] in Munteanu I. et al, Moldova pe calea democrației şi stabilității din spațiul post-sovietic în lumea valorilor democratice, IDIS Viitorul, 2005, p. 124 (in Romanian).

${ }^{46}$ Busuncean T., "Separatism in the Black Sea and Caspian Sea Region as a Source of International Terrorism", Combating Terrorism Working Group, PfP Consortium https://consortium.pims.org/filestore2/ download/2339/ctwg separatism in the black sea.pdf

${ }^{47}$ Trilateral Plan for Solving the Transnistrian Issue. Regional Partnership for a Common Commitment Oriented Approach (note 43), p. 7-9.
} 
agreement comes into the force ${ }^{48}$. Nevertheless, Russia has never implemented this agreement.

Since 1997, the resolution of the Transnistrian conflict has been negotiated in format "5-2" (Moldova, Transnistria, Russia, Ukraine and OSCE plus EU and USA as the observers included in the format in 2005). Still negotiations are ineffective due to asymmetry of power: Russia in fact has two voices against one Moldova's voice, at the same time all the rest participants of negotiations have been acting more as observers, not as mediators. Also direct meetings of Moldovan and Transnistrian representatives at the "initiative" of one of the sides are in the deep deadlock (the sides haven't met for eight years already). This refers to the few interest of one of the sides in resolving the conflict.

In 2003 Moscow offered Chisinau to resolve the Transnistrian conflict by forming a federal state of Moldova. The plan of Moldova's federalization, foreseen in Kozak memorandum (the author of this plan - Dmitry Kozak, former deputy head of President's administration of Russian Federation), raised a grave negative reaction both from Moldovan civil society, the EU and the West. The Kozak memorandum was rejected for several reasons. First, it foreseen disproportional participation of Transnistria's representatives in the central structures of common government institutions, what provided the breakaway region with blocking minority in common state institutions. Second, Kozak memorandum foreseen that Russian armed forces would remain in Moldova's territory until $2020^{49}$. Moldova, seeking the fastest possible withdrawal of Russian military forces from its territory, foresaw this provision as attempt for its indirect occupation.

Frozen conflict with Transnistria has been the main source of threats to Moldova's national security. First and foremost, only due to the existence of frozen separatist conflict Moldova encounters the permanent threat to its territorial integrity.

Secondly, Russian military forces, dislocated in Transnistria, raises the hard security threat, especially when Moldova itself has small military forces (small professional armed forces, designed for assisting to keep public order inside the country and to participate in international peacekeeping operations) ${ }^{50}$. As the Georgian precedent of August 2008 has shown, Russian armed forces, dislocated in Moldova, could be used against Moldova at any moment.

Thirdly, the Soviet "heritage", left in Transnistria - a huge arsenal of guns and ammunition - raises threats of both hard and soft security. The bigger part of guns, kept in the Kolbasna (Transnistria) ammunition store, is in very poor state. It is worth mentioning that during the Cold War, the Kolbasna ammunition store was the biggest gun store in Europe. According to

\footnotetext{
${ }^{48}$ Solomon C., Gumeniuc A., "Conflictul Transnistrean şi procesul de negocieri în formatul "5+2"”' ["Transnistrian Conflict and it‘s Regulation Process in " $5+2$ " Format], MOLDOSCOPIE (Probleme de analiză politică), Nr. 3 (XLII), 2008, p. 176 (in Romanian).

${ }^{49}$ Solomon C., Gumeniuc A. (note 48), p. 178.

${ }^{50}$ Mocanu Gh. (note 26), p. 243.
} 
the independent estimations, in Kolbasna there could be dislocated about 10 thousand tons of explosives (throtyl), the explosion of which would equal the explosion of atomic bomb in Hiroshima in $1945^{51}$. Due to it being in such poor state it is dangerous to transport the weapons, the optimal solution would be to destroy the out-dated ammunition at the place. Nevertheless, seeking to avoid environmental threats (it could lead to the increase of the pollution of Dniestr), the special costly technologies for destroying the weapons should be used. One of the reasons, why Russia stalls the withdrawal of its military forces from Moldova's territory, is that Russia still cannot afford the destruction of the outdated military equipment.

Fourth, Transnistria, ruled by illegal criminalized regime, has become the regional "centre" of illegal weapons trade. Transnistria has not only the huge reserves of Russian military equipment (objectively it should be mentioned that soviet ammunition acts more as an environmental threat then a threat to the hard regional security), but also holds the full cycle of the weapons production. In region metallurgic factory, the factory of mechanic parts for ammunition are operating, the factory "Elektromash" produces shooting weapons of several types, plant "Tolikomash" produces anticipators of mines and has no analogue in the whole CIS. Moreover, it has been disclosed that Transnistria provided weapons for Abkhazia, the breakaway Georgian region ${ }^{52}$. So, Transnistria could provide weapons also for terrorist and extremist groups.

Weapons trade is not the only one illegal activity of Transnistria, which due to weak border control, acts as a "black hole" for organized crime (trade in arms, drugs and people). Huge amounts of contraband are directed through Transnistria. In 2005 the EU Border Assistance Mission (EUBAM) was dislocated at the Moldova (Transnistria)-Ukraine border. Since 2005 the amount of contraband significantly decreased, but still it remains relatively high. Only in 2008, at the Moldova-Ukrainen border and only in official cross-border checking points about 300 illegal cargos, worth some 1 million euro, were intercepted at the custody ${ }^{53}$. On $3^{\text {rd }}$ March 2006 Moldova and Ukraine began to implement the new custody order, according o which all export goods from Transnistria had to receive stamps of Moldovan custody. This order was called "economic genocide" by Transnistria leaders. The vocal fact is that Russia supported the separatist region and even allocated humanitarian assistance for it.

Ultimately, Transnistria has been acting as Russia's instrument for controlling Moldova's foreign policy and to maintain country's neutrality. The perfect illustration of this tendency is Kozak memorandum, proposed in 2003, which, if implemented, would have transformed Moldova into Russia's vassal. Moreover, Russia has actively supported the nationalist and extremist youth organizations in Transnistria, educating the opponents of reintegration

\footnotetext{
${ }^{51}$ Busuncean T., "Separatism in the Black Sea and Caspian Sea Region as a Source of International Terrorism" (note 46).

${ }^{52}$ Asarov B. (note 45), p. 129-130.

${ }^{53}$ Mocanu Gh. (note 26), p. 238.
} 
with Moldova and Moldova's pro-European orientation. Most active and most numerous youth organizations in Transnistria are "Proryv" ("Outbreak") and the youth branch of Russian National Bolshevik Party. When necessary, these organizations could act on behalf of local forces, dissatisfied with Moldova's policy. Two terrorist acts have already been tied to these organizations: in the spring of 2006 - the explosion of grenade in public transport in Tiraspol, and similar act in October 2009 in Chisinau during the public concert ${ }^{54}$.

Due to the unresolved conflict with Transnistria Moldova has been seen by the international community as a single-issue country ${ }^{55}$, what hinders Moldova from receiving multi-sided attention from international partners and to follow the path of sustainable development.

Moldova's security strategy of neutrality, which had to facilitate the compromise with breakaway Transnistria, still hasn't provided with any results. Moreover, the paradox is that the Transnistrian conflict, due to which Moldova was forced to adopt neutrality, is the main obstacle to recognize Moldova's neutrality. At the same time Moldova is a "hostage" of unilaterally declared neutrality, because efforts to change the security strategy could provoke the shift of Transnistrian conflict from the frozen to an active phase.

\subsubsection{Challenges for Moldova after Russian-Georgian War}

The unpredicted armed conflict of August 2008 between Russia and Georgia, was a serious signal that has reminded of Moldova's security "deficit" and has stimulated the discussions on the efficiency of country's security strategy.

First and foremost, Moldova understood that it could become the next victim of Russia's aggression. This threat has been heightened by the fact that Moldova has been "punished" by Russia several times already. In 2006, after pesticides were claimed to be found in Moldovan wines, the import of Moldova's wine production to Russia was forbidden ${ }^{56}$ (the import has not been fully restored until now). At the same time embargo for Georgian mineral water and wines also was introduced by Russia. Until the restrictions of imports, some 90 percent of Moldova's wine production was directed towards Russian market. So, it goes without saying that the closing of Russian market for Moldova's main export production should have had political reasons - it was Russia's "revenge" for Moldova's increased European and Euro-Atlantic ambitions. In 2005, Moldova and the EU signed a three-year Moldova-EU Action Plan, in 2006 - biannual Moldova-NATO Individual Partnership Action Plan (IPAP), in 2005 EUBAM was dislocated at the border of Moldova-Ukraine.

\footnotetext{
${ }^{54}$ From the interview with associated expert of IDIS Viitorul, Mgr. Vitalie Grosu, October 2009, Chisinau. ${ }^{55}$ Mînzărari D., Ioniță V., In NATO We Trust? Explaining Why Moldova Would Need to Join NATO, Discussion Papers, Debate on Current Affairs Series No. 3, October 2008-January 2009, IDIS Viitorul, p. 7.

${ }^{56}$ Munteanu I. et al, 100 cele mai presante probleme ale Republicii Moldova in 2006 (note 18), p. 77.
} 
Secondly, the threat for Moldova's territorial integrity, raised by RussianGeorgian war, became more relevant than ever before. After Russia provided Abkhazia and South Ossetia with de jure recognitions, the possibility that Moscow could any time repeat this scenario with Transnistria significantly increased. It is interesting that Russia demonstrated Moldova it's increased influence immediately - already the next day after the de jure recognition of Abkhazia and South Ossetia Moldova was reminded of the Kozak memorandum, which was rejected by the latter in $2005^{57}$.

Thirdly, armed conflict between Russia and Georgia pushed the whole Eastern Europe, which has already been situated in the "grey zone", towards even deeper "vacuum of power". In August 2008 at their meeting of Heads of NATO in Bucharest Georgia and Ukraine were refused to provide with Membership Action Plans (MAP). After the Russian-Georgian war talks of Georgia's and Ukraine's possible membership in NATO have silenced at all. The attention of USA to Eastern Europe significantly decreased after 2009, when President's Obama administration turned towards the new stage of "reset" in the relations with Russia. On the other hand, after August 2008 the role of Russia as a guarantee of security in Eastern Europe was definitely rejected. Currently Eastern European countries, including Moldova, are left with the only possibility - to wait for the outcomes of the new stage in USARussia relations.

Nevertheless, ongoing changes in global security environment and growing tension in the Eastern Europe after Russian-Georgian war does not eliminate the problems of Moldova's neutrality security strategy. In reverse, Russian-Georgian war have demonstrated that the use of military force against the state is returning to the list of options of foreign policy. ${ }^{58}$. In this context, the question of external guarantees of security should be of primary importance, especially for the small state.

Moldova, recognizing the threat to become the continuality of Georgian precedent, is intended to refer to the factor of the NATO neighbourhood. Moldova's government hopes that Russia should not take a decision to attack the country, which borders the NATO member Romania ${ }^{59}$. One of the reasons for ruling "Alliance for European Integration" to strengthen ties with Romania is the creation of "indirect" security shield for Moldova. Nevertheless, in spite of the growing importance of Romanian factor in Moldova's security policy, Romania's influence for Moldova's security strategy in the short-medium term will remain indirect. The paradox is that direct Romania's efforts to influence the security strategy of neighbour Moldova could provoke contrary effect. First, as it has already been mentioned, a large part of Moldova's society

\footnotetext{
${ }^{57}$ Markedonov S., ““The Georgian Crisis”, New Realities and Rules of Game” in The Black Sea Region: a Security Minefield or a Partnership Road, \#4 Disscussion Papers, Intra-Regional Perspective of the Black Sea Affairs.

${ }^{58}$ Mînzărari D., Ioniță V., In NATO We Trust? Explaining Why Moldova Would Need to Join NATO (note 55), p. 18.

${ }^{59}$ Mocanu Gh. (note 26), p. 225-226.
} 
still remains Romanian-phobic. So, the more active Romania would support Moldova's refusal from neutrality, the more Moldova's society would defend the maintenance of the current security strategy. Second, Russia's reaction towards Moldova's relations with Romania, especially - in the security policy, it would be much more sensitive than that of Moldova's cooperation with the NATO.

\subsection{NATO in Moldova's Security Agenda}

One of the greatest shortcomings of Moldova's neutrality strategy restricted possibilities to choose external partners in the field of security. Nevertheless, analyzing from pluralist perspective, Moldova has found a way to bypass the rigid neutrality security strategy - the cooperation with Western security structures, especially - with NATO.

One of the strongest arguments for Moldova to choose a neutrality security strategy, was the reluctance to participate in Russian-dominated post-soviet security structures, such as Collective Security Treaty Organization (CSTO). Until now Moldova has managed successfully to bypass all the issues of security dimension in the framework of CIS (the country does not participate in common military trainings and so on). Thus, the neutrality strategy does not withhold Moldova from developing cooperation with NATO, at the same time avoiding Russia's reaction.

The cooperation between Moldova and NATO began in 1994, when Moldova joined the Partnership for Peace (PfP) programme. Moldova became the second CIS state (after Ukraine) to join $\mathrm{PfP}^{60}$. It is interesting that Malta, which joined PfP year later, after the change of government withdrew from this format of cooperation by reasoning the withdrawal by the efforts to maintain the neutrality ${ }^{61}$.

In 1997 Moldova joined the Partnership Planning and Review Process (9PARP), the same year the cooperation with Alliance in the scientific sphere was started ${ }^{62}$. In 2006, NATO and Moldova signed Individual Partnership Action Plan (IPAP), adopting the Plan to the Moldova's status of permanent neutrality and reflecting country's EU integration goal ${ }^{63}$. In the fall of 2006 NATO held in Moldova two military trainings - Cooperative Longbow and Cooperative Lancer. In 2007 Moldova hosted international military trainings Medceur- $07^{64}$.

The main advantage of Moldova's neutrality status in the context of cooperation with NATO is - the development of the country's relations with

\footnotetext{
${ }^{60}$ Druc E., "North-Atlantic Alliance Cooperation Policy: Partnership for Peace" in European and NATO Neighboring Policies - New Dimensions for Regional Ccooperation, Training Seminar, Chisinau, Republic of Moldova, November 28-29, 2007, p. 28-29.

${ }^{61}$ Druc E. (note 60), p. 29.

${ }^{62}$ Druc E. (note 60), p. 30-31.

${ }^{63}$ Druc E. (note 60), p. 33.

${ }^{64}$ Marandici I. (note 21), p. 48.
} 
the Alliance does not provoke harsh Russia's reaction (contrary as in the case of Georgia). Moreover, Moldovan society is quite positive regarding the NATO. Analyzing the data of public opinion surveys, an interesting detail is mentioned: according to the surveys, to the question "What would be the optimal way to guarantee Moldova's security?", only 16.3 percent of society would choose NATO membership as an alternative to neutrality. But, asked "How would you vote, if referendum on Moldova joining the NATO would take place tomorrow?", already 22 percent of questioned would be in favour of Moldova's NATO membership ${ }^{65}$. These ambiguous results indicate, first, that that Moldova's society, as political elite, treats country's neutrality as an axiom (unquestionable fact). Second, the results of the surveys also indicate that NATO in Moldova is perceived more as a political organization than military block ${ }^{66}$, so the intensive cooperation with NATO does not challenge the country's neutral status.

Close cooperation with NATO is important for Moldova in several aspects. First, in the framework of IPAP (participation of Moldova's military forces in common military and civil trainings with NATO and in other instruments of cooperation), Alliance helps Moldova to indicate the directions for reforming country's security and defence sector, shares know-how of its members in this sphere. Having in mind the intermediate position of Moldova's government towards the reforming country's security and defence sector, the assistant and encouragement from the part of NATO is especially important. Cooperation with NATO has the biggest value-added on the issues of democratic control of armed forces, the cooperation between military forces and civilians and increasing the transparency of management of military sector.

Secondly, cooperation with NATO allows Moldova to remain on the Euro-Atlantic security agenda. After Romania joined NATO and Moldova became the "direct" neighbour of the Alliance, Moldova's importance for the NATO significantly increased. Moreover, NATO as an international organization, which disposes high level of prestige in international arena, plays significant role in maintaining and developing Moldova's ties with particular NATO members. Direct contacts with NATO member states help Moldova to overcome the detrimental image of a "single issue state".

Thirdly, close cooperation with NATO is an integral part of Moldova's euro-integration policy. Currently we can speak of "functional sharing" between the EU and NATO, where NATO has taken on the responsibility for guaranteeing the security of Euro-Atlantic space (EU efforts to develop its own military forces does not challenge the role of NATO in Euro-Atlantic space). The fact that all new EU members are also the NATO's members could be directly linked to the need of ensuring Euro-Atlantic security.

So, on the one hand, neutrality creates the favourable conditions for Moldova to develop cooperation with NATO, at the same time avoiding the

\footnotetext{
${ }^{65}$ Barometrul Opiniei Publice, Republica Moldova, Noiembre 2009 (note 32), p. 110-111.

${ }^{66}$ Munteanu I. et al, 100 cele mai presante probleme ale Republicii Moldova in 2006 (note 18), p. 211.
} 
irritation of Russia. Nevertheless, on the other hand, unilaterally proclaimed country's neutrality restricts Moldova's possibilities to seek NATO membership. The elimination of NATO membership option from the Moldova's security policy agenda is a serious problem with various implications ${ }^{67}$.

First of all, if Moldova prepares for a real euro-integration (this means Moldova is decided one day to become full member of EU), the realization of this goal would be hardly successful without NATO's membership due to several reasons. Firstly, it is less likely that the EU would decide to take full responsibility for ensuring the security of neutral Moldova, especially having in mind Russia's influence and possible manipulations (this tendency is valid for the whole Eastern Europe). Secondly, NATO is not only the organization of collective defence, but also the instrument for promoting the democratic and Western standards in the security sector. So, the process of democratization and the consolidation of democracy in the state, which has moderate ties with $\mathrm{NAYO}$, could be slower and not so multidimensional.

Secondly, currently NATO is the only one Euro-Atlantic security organization, providing real defence quarantines for its member states. All the others universal or regional security organizations, "accessible" for Moldova, are either too much so influenced by Russia (for example UN, OSCE) and for this reason incapable to add to the resolving of Moldova's security problems, or operating more like the "clubs for political discussions in the field of security" (for example, GUAM).

Third, today NATO is the only political-military force, capable to carry out effective deterrence of conventional military threats. In this regard, NATO membership would help Moldova to solve the problem of Russia's pressure and manipulation, at least in the sphere of hard security ${ }^{68}$.

In addition, Moldova's NATO membership perspective would have a positive "by-effect" - it would be one more common interest with neighbouring Romania. This would lead to the intensity of bilateral cooperation in various fields. Moreover, the appearance under the common "security umbrella" (or at least the streaming to appear there) would increase trust between the neighbours. Intensified ties and enhanced trust would help to resolve the problem of Moldova's "divided" identity.

The democratic political forces, which came into the power after the July 2009 early elections, view the cooperation with NATO much more positively and seriously than communists. But the threat remains that the NATO issue could become the cleavage line inside the coalition. Two of four parties, forming the "Alliance for European Integration" - Liberals and Liberal Democrats - support the review of Moldova's neutrality (what would open at least

\footnotetext{
${ }^{67}$ Gorincioi R., "Elaborarea noi concepți de securitatea naționala prin prisma cooperării cu Alianța NordAtlantică" ["Elaboration of New National Security Concept from the Perspective of Cooperation with NorthAtlantic Alliance] in Studii internaționale: Viziuni din Moldova. Publicație periodică ştințifico-metodică, Vol. IV, Nr. 3, 2007, p. 18 (in Romanian).

${ }^{68}$ Mînzărari D., Ioniță V., In NATO We Trust? Explaining Why Moldova Would Need to Join NATO (note 55), p. 34.
} 
theoretical possibilities to Moldova's NATO membership). At the same time Democratic party and Alliance "Our Moldova" are more likely to preserve Moldova's neutral status.

Looking from the pluralist perspective, Moldova's neutrality means the "neutralization" of the pressure to intensively cooperate with Russia in the sphere of security, but not the aspiration to remain outside military alliances in general. So, it is likely, that, in case of the weakening of Russia's factor in Moldova's security policy, the NATO membership perspective would become an option for Moldova.

\section{Conclusions}

Moldova's neutrality security strategy, chosen more than 15 years ago, failed to help the state to overcome the main security challenges. The inefficiency of Moldova's security strategy was determined by several factors.

First of all, Moldova's neutrality security strategy has failed to prove itself because of the mistaken perception. Moldova's neutrality, although was not explicitly explained in the strategic documents, was grounded not on the geopolitical argument - willingness to avoid the "zone of high geopolitical tension", but on the threat of hard security - unwillingness to irritate Russia, which deployed it's military forces inside the state, also - on the reluctance to participate in the Russian-dominated security structures.

Secondly, the main function, foreseen for neutrality, was to facilitate the resolving of the conflict with breakaway Transnistria. But, although the conflict really is between Moldova and Russia, not between Moldova and Transnistria, Chisinau's choice on neutrality was the big victory of Moscow. If Moldova remains neutral, this means - without external security guarantees, Russia gets the leverage to "freeze" the resolution of Transnistrian conflict as long as it is beneficial for the own interests of Russia. The determinant role of the Russian factor for Moldova's security strategy is confirmed by the fact that at the time of declaring independence Moldova had been already faced with the problem of separatism. Nevertheless the 27 August 1991 Declaration of Independence has no reference to neutrality. The turning point in Moldova's security strategy is observed after the signing of the cease-fire agreement between Moldova, Russia and Transnistria, which opened the way for undetermined presence of Russian military forces in Moldova's territory. So, it could be concluded that Moldova's neutrality is the reflection of Russia's interests.

In addition, the neutrality security strategy has not only failed to add to the resolution of Moldova's security problems, but even may challenge the smooth realisation of the country's national interests in the medium-long term. Especially it is said about the Moldova's NATO membership perspective - rejecting the NATO membership may cost EU membership perspective for Moldova. 
The process of the review of country's Constitution, planned for 2010, gives some hopes that the status of permanent neutrality may be reconsidered once more. "Alliance for European Integration", currently forming the ruling majority, is intended to use the period in institutional crisis in Moldova for the review and correction of the country's strategic goals and guidelines. Until the mid-2010, when the parliament should be dissolved and the new early parliamentary elections announced, Moldova's society would be mostly concentrated on the issues of going out of institutional deadlock and the relation between authority branches. Moreover, the practice shows that during times of economic hardship society is less interested in the questions of security. So, Moldova's security issues, if overviewed in the nearest future, most likely would not provoke the "wave of opposition" inside the country.

However, as the analysis, presented in this article, shows, Moldova's neutrality is the outcome of the country's confusion within the new geopolitical situation. Accordingly, the technical rejection of neutrality would hardly bring any essential changes. Moldova's government, aiming to create a stable background and favourable conditions for the new security strategy, should pay most of its attention towards minimizing Russia's influence, solving the problem of a "divided" identity, diversifying country's external relations and developing ties with the international community. 